\title{
Dural metastatic adenocarcinoma mimicking meningioma
}

\section{Figure $\quad$ MRI}
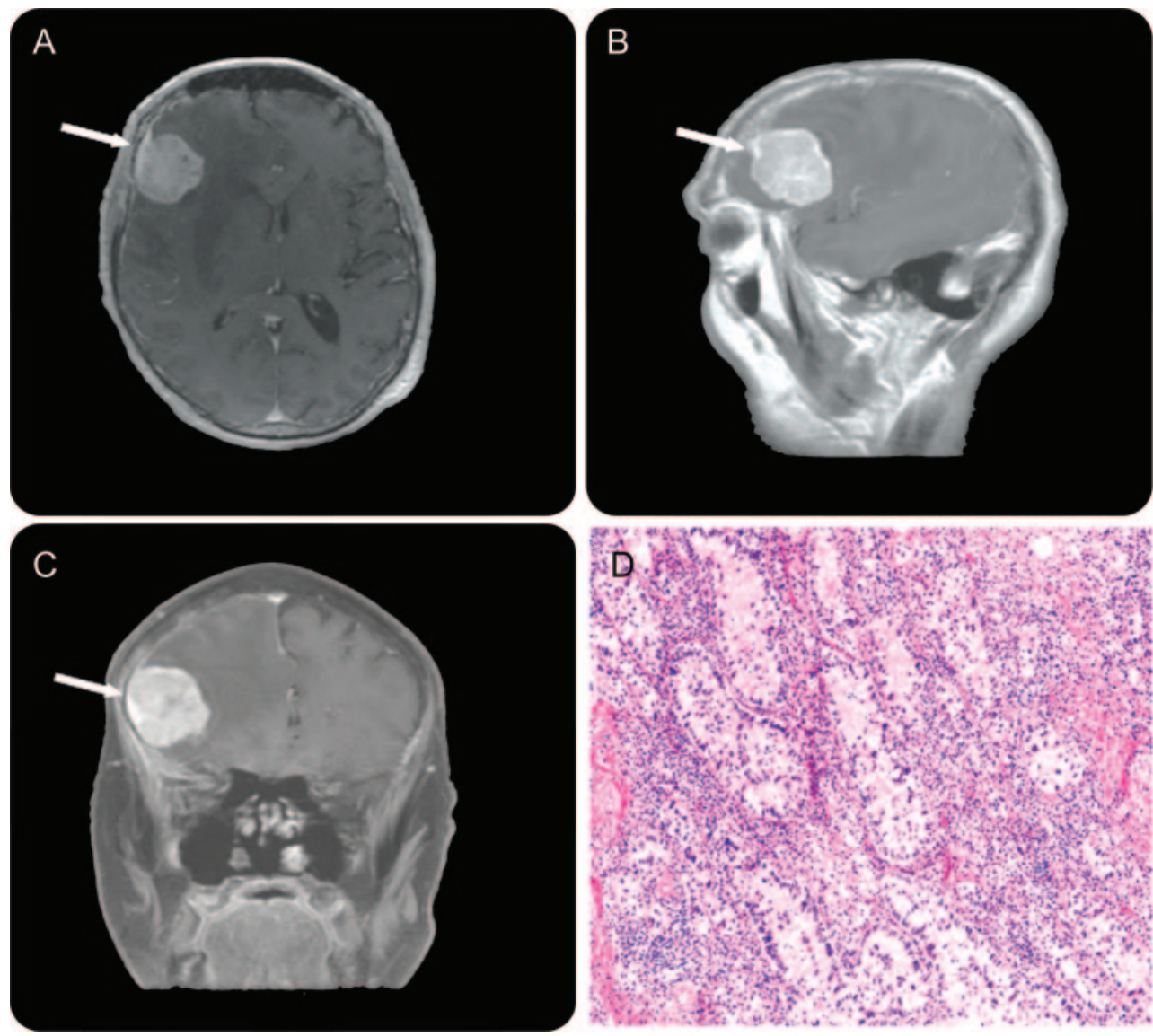

Axial (A), sagittal (B), and fat-saturated coronal (C) gadolinium-enhanced T1-weighted MRI show a homogeneously enhanced extra-axial mass with adjacent marrow enhancement and dural tail sign; thickening of enhanced dura extending from the mass (white arrow). (D) Hematoxylin \& eosin-stained tumor specimen consistent with moderately differentiated adenocarcinoma.

A 69-year-old man presented with progressive left upper extremity weakness and recurrent falls. A right frontal extra-axial mass with dural tail, highly suggestive of meningioma, ${ }^{1}$ was found on MRI (figure). However, excisional biopsy revealed features consistent with metastatic adenocarcinoma. Subsequently, a left hilar mass with mediastinal lymphadenopathy was discovered.

The characteristic appearance of meningioma should be sought in all imaging sequences in order make pertinent differential diagnosis. Although rare, dural metastases from more aggressive neoplasm can mimic classic radiologic appearance of meningioma. Metastases with dural extension are mostly reported from prostate, lung, and breast primaries. ${ }^{2}$

Amir Kheradmand, $M D$, and Thomas Smith, MD, Worcester, $M A$

Disclosure: The authors report no disclosures.

Address correspondence and reprint requests to Dr. Amir Kheradmand, Department of Neurology, University of Massachusetts Medical School, 55 Lake Avenue North, Worcester, MA 01655; amir.kheradmand@umassmemorial.org

1. Goldsher D, Litt AW, Pinto RS, Bannon KR, Kricheff II. Dural "tail” associated with meningiomas on Gd-DTPA-enhanced MR images: characteristics, differential diagnostic value, and possible implications for treatment. Radiology 1990;176:447-450.

2. Laigle-Donadey F, Taillibert S, Mokhtari K, Hildebrand J, Delattre JY. Dural metastases. J Neurooncol 2005;75:57-61. 


\section{Neurology}

\section{Dural metastatic adenocarcinoma mimicking meningioma \\ Amir Kheradmand and Thomas Smith \\ Neurology 2010;74;1396 \\ DOI 10.1212/WNL.0b013e3181dad61a}

This information is current as of April 26, 2010

Updated Information \&

Services

References

Subspecialty Collections

Permissions \& Licensing

Reprints including high resolution figures, can be found at: http://n.neurology.org/content/74/17/1396.full

This article cites 2 articles, 0 of which you can access for free at: http://n.neurology.org/content/74/17/1396.full\#ref-list-1

This article, along with others on similar topics, appears in the following collection(s):

\section{MRI}

http://n.neurology.org/cgi/collection/mri

Information about reproducing this article in parts (figures,tables) or in its entirety can be found online at:

http://www.neurology.org/about/about_the_journal\#permissions

Information about ordering reprints can be found online:

http://n.neurology.org/subscribers/advertise

Neurology ${ }^{\circledR}$ is the official journal of the American Academy of Neurology. Published continuously since 1951, it is now a weekly with 48 issues per year. Copyright. All rights reserved. Print ISSN: 0028-3878. Online ISSN: 1526-632X.

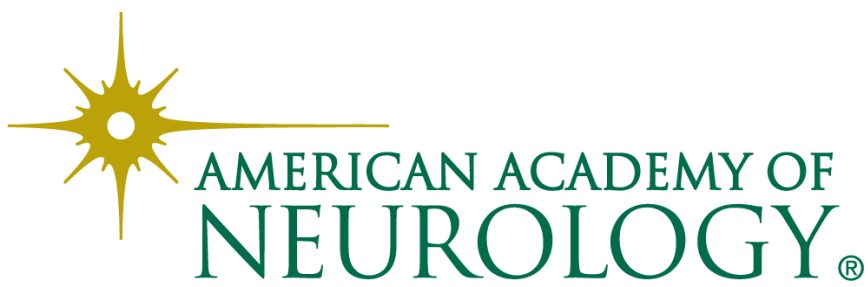

